\title{
IMPLEMENTATION OF PRECAUTIONARY PRINCIPLE IN COAL MINING LICENSES IN CENTRAL BENGKULU REGENCY OF BENGKULU PROVINCE
}

\author{
By: \\ Dede Frastien, Edra Satmaidi, Iskandar
}

\begin{abstract}
Coal mining license is a juridical instrument for businessmen to carry out coal mining activities. Coal mining license is also a preventive instrument to prevent coal mining activities from causing environmental damage and pollution. In the process of issuing and implementing coal mining licenses according to Law Number 32 of 2009 concerning Environmental Protection and Management, one must consider the precautionary principle, which is implemented by integrating environmental considerations, in making coal mining licenses decisions. However, coal mining activities carried out by 9 coal mining companies in the Watershed of Air Bengkulu, showed that there was environmental destruction and pollution seen along the Watershed of Air Bengkulu. This study aimed to determine the application of the precautionary principle to coal mining licenses and the legal consequences of coal mining license decisions that did not apply the precautionary principle. This research was conducted using juridical empirical/socio-legal research, and data analysis was carried out using a qualitative juridical approach. The results of this research showed that the government of Bengkulu Province has not applied the precautionary principle in the process and implementation of coal mining license in the Watershed of Air Bengkulu of Central Bengkulu Regency. The legal consequence of not applying the precautionary principle in the decision to issue 9 (nine) coal mining licenses which was an essential and material requirement in a decision to issue a permit was null and void (nietig van rechtwege) and could be canceled (vernietig baar), the government of Bengkulu Province has the authority to cancel the licenses decision because it is a State Administration official.
\end{abstract}

Key words: Application, Precautionary Principle, Licenses, Coal Mining 


\section{A. INTRODUCTION}

\section{Research Background}

One of the objectives of the state contained in the fourth paragraph of the 1945 Constitution of the Republic of Indonesia (hereinafter referred to as the 1945 Constitution) is "to protect the entire Indonesian nation and all the spilled Indonesian blood, and to promote the general welfare". To achieve this goal of a state, a state organization is required to determine the division of tasks and powers for all the people. ${ }^{1}$

The environmental management policy in Indonesia has actually been explicitly mandated in Article 33 verse 3 of the 1945 Constitution which has outlined that "Earth and water and natural resources contained therein are controlled by the state and used for the greatest prosperity of the people". ${ }^{2}$ This article mandates the government as state administrator to be able to properly manage the earth, water and the wealth contained therein for the

\footnotetext{
${ }^{1}$ R. Abdoel Djamali, Pengantar Hukum Indonesia, Rajawali Pers, Jakarta, 2010. Pg. 128.

${ }^{2}$ Emil Salim, Thoby Mutis. Instrumentasi dan Standarisasi Kebijakan Pengelolaan Lingkungan Hidup, Penerbit Universitas Trisakti, Jakarta, 2009. pg. 5.
}

greatest possible prosperity of the people. Apart from that, Article 33 verse (3) also describes the sustainable and environmentally sound development carried out by the Indonesian state. ${ }^{3}$

Thus, it can be said that in fact Article 33 verse (3) of the 1945 Constitution of the Republic of Indonesia has laid a constitutional basis for the use and management of living natural resources and their ecosystems in Indonesia in line with the concept of sustainable development. ${ }^{4}$

Article 33 verse (4) "The national economy shall be carried out based on economic democracy with the principles of togetherness, equitable efficiency, sustainability, environmental insight, independence, and by maintaining a balance between progress and national economic unity." The National Economy is intended as a very important signpost in the effort to realize economic democracy in Indonesia. It is the people's welfare

\footnotetext{
${ }^{3}$ Abrar Saleng, Hukum Pertambangan,
} Universitas Islam Indonesia Press, Yogyakarta, 2004. pg. 40.

${ }^{4}$ Abdulah Marlang dan Rina Maryana, Hukum Konservasi Sumber Daya Alam Hayati dan Ekosistemnya, Mitra Wacana Media, Jakarta, 2015, pg. 7. 
that is prioritized in order to achieve sustainable development. ${ }^{5}$ Likewise, the state guarantees the rights of citizens to obtain basic rights to a good and healthy environment as stipulated in Article 28H verse (1) of the 1945 Constitution of the Republic of Indonesia.

Sustainable development is generally defined as the development of ideas about the importance of insight into the maintenance, preservation and protection of a healthy environment. ${ }^{6}$ The concept of sustainable development aims to synchronize, integrate and give equal weight to the main aspects of development, which include not only environmental aspects, but include several surrounding aspects, including socio-cultural and economic aspects. These main aspects should be viewed as closely related to one another, so that the elements of this interrelated

\footnotetext{
5 This article has published in Kompas.com entitled "Kembali ke Pasal 33 UUD $1945^{\prime \prime}$,

https://nasional.kompas.com/read/2011/12/22/02061513 /Kembali.ke.Pasal.33.UUD.1945. Retrieved on September $10^{\text {th }}, 2020$ at 12.09 WIB

6 Jimly Asshiddiqie. Green constitution, Nuansa hijau Undang-undang Dasar Negara Republik Indonesia Tahun 1945, Rajawali Pers, Jakarta, 2010. pg, 133.
}

unity should not be separated or contradicted one another. ${ }^{7}$

In realizing the use of natural resources for the prosperity of the people and guaranteeing the basic rights of citizens to a good and healthy environment, it is necessary to protect natural resources and the environment for the prosperity of the people. One way of this protection can be realized by the existence of good legal rules. Good law is when it contains the values of justice for all people, in that context, the law also functions as a tool of justice (law as a tool to reach justice) in the use of natural resources and the environment. Such justice is called environmental justice. $^{8}$ In realizing this right to justice over natural resources and the environment, it is necessary to carry out an integrated and integrated manner between the marine, land and air environments. This is in line with the mandate of Article 2 letter d of Law Number 32 Year 2009 concerning Environmental Protection and

7 Josef. Thessing dan Wilhelm Hofmeister, Environment and Development Protection as An Element of Order Policy, Rathausallee: Konrad Adenauer Stiftung, 1996.pg. 64.

${ }^{8}$ NHT. Siahan, Hukum Lingkungan, Cetakan Kedua, Pancuran Alam, Jakarta, 2009. pg. 49-50. 
Management, which states that environmental protection and management must be implemented based on the principle of state responsibility; sustainability and sustainability; harmony and balance; cohesiveness; benefits; caution; justice; ecoregion; biodiversity; polluter pays; participative; local culture; good governance; and regional autonomy. ${ }^{9}$ Furthermore, it must also be held based on the principles of sustainable and environmentally sound development as contained in the weighing section of Law Number 32 of 2009 concerning Environmental Protection and Management.

However, in its implementation, the state is often faced with a dilemma to apply the principles and principles of environmental management and protection as described above, in the context of optimal utilization with environmental and social losses. Ideally, the state should undertake efforts to protect and manage the environment based on mutually agreed upon norms,

9 Efendi, Penerapan Prinsip Pengelolaan Hidup Dalam Peraturan Perundang-Undangan di Bidang Sumber Daya Alam, Kanun Jurnal Ilmu Hukum, No. 58 Tahun XIV (Desember 2012). pg. 350. principles and principles for environmental protection and management, meaning in a balanced manner between economic interests, preservation of environmental functions and social conditions. Protection and management are carried out in an integrated manner covering all areas of the environment for the sustainability of environmental functions. In the end, balance and sustainability will be achieved in the welfare of the community as described above. In environmental protection and management, state administration is the dominant party. The dominance of the government is a consequence of a welfare state. ${ }^{10}$

Damage to the environment and natural resources as well as ecological impacts that occur actually begins with a policy of development and management of natural resources that does not consider the preservation of environmental functions and does not apply the principles of environmental protection and management, one of which is the

\footnotetext{
${ }^{10}$ Helmi, Hukum Perizinan Lingkungan Hidup, Cetakan Pertama, Sinar Grafika, Jakarta, 2012, pg. 46.
} 
precautionary principle. $^{11}$ The government often issues an activity/business licenses policy that does not pay attention to environmental instruments and does not apply the principles of environmental protection and management. The problems that occur are a lot of space utilization that is not in accordance with spatial planning and does not pay attention to the carrying capacity of the environment which cannot be denied that all of them have caused damage and destruction to natural resources and the environment. Even worse, there is coal mining in the forest area which is a watershed in one of the provinces in Indonesia, Bengkulu Province.

The Government of Bengkulu Province in terms of issuing and supervising permits, especially in the coal mining sector, was indicated to have not applied the precautionary principle, if it was observed that the precautionary principle indicated that the state needed to be careful in

${ }^{11}$ Edra Satmaidi, “Kajian Lingkungan Hidup Strategis (KLHS) dalam Menjamin Terpeliharanya Daya Dukung dan Daya Tampung Lingkungan Hidup (DDDTLH) Bagi Pembangunan Berkelanjutan", Indonesian Journal Of Dialectics, vol. 5, No 3 Desember 2015. Pg. 128. making its policies. The activities which have the potential to cause serious and irreversible impacts which in this principle must be prevented. In this case, the lack of scientific certainty could not be used as an excuse for delaying prevention efforts. ${ }^{12}$ The fact is that the Government of Bengkulu Province has granted business activity permits for coal mining in Central Bengkulu Regency, which is the Watershed of Air Bengkulu. A watershed area which is a forest area, is an area designated as protection and is a life-support area where cultivation activities should not be carried out. In the upstream area of the Watershed of Air Bengkulu, there are 9 coal mining licensess, both who are still active and not. All of them have been very massive in damaging the Watershed since 1986 and causing ecological disasters of floods and landslides almost every year. The companies are as follows: PT. Kusuma Raya Utama, PT. Bara Mega Quantum, PT. Inti Bara Perdana, PT. Ratu Samban Mining, PT. Griya Pat Petulai, PT.

12 Liza Farihah \& Femi Angraini, Prinsip Kehati-Hatian Dan Kerugian Potensial Dalam Perkara Tata Usaha Negara Terkait Lingkungan Hidup, Jurnal Yudisial Vol. 5 No. 3 Desember 2012, pg. 245. 
Danau Mas Hitam, PT. Cipta Buana Seraya, PT. Bukit Sunur, PT. Bengkulu

Bio Energy.

The Government of Bengkulu Province should not issue coal mining licenses in the Watershed of Air Bengkulu, because as it is known, a watershed is required to have a water catchment area where the area is provided for the entry of water into a forest area. Forest area is a certain area designated and/or stipulated by the government to maintain its existence as permanent forest. State forest area, the legal status is that the forest belongs to the State. ${ }^{13}$

From the explanation above, there was a deviation development with the argument of the people's welfare that has an impact on ecological disasters and the destruction of natural resources in a structured and planned manner, which was an extraordinary environmental crime. This occured as a result of the policy in the issuance of licenses instruments carried out by the Government of Bengkulu Province which has never

${ }^{13}$ Iskandar, Hukum Kehutanan Prinsip Hukum Pelestarian Fungsi Lingkungan Hidup Dalam Kebijakan Pengelolaan Kawasan Hutan Berkelanjutan, CV. Mandar Maju, Bandung, 2015, pg. 1. paid attention to and applied the precautionary principle, environmental instruments and the objectives of environmental protection and management, especially paying attention to the carrying capacity of the environment. Based on the background previously disclosed, the authors were interested in raising it in a scientific paper in the form of a thesis entitled "Application of Precautionary Principles in Coal Mining Licenses at the Central Bengkulu Regency of Bengkulu Province".

\section{Identification of problems}

How was the application of the precautionary principle in the issuance of coal mining licenses at Central Bengkulu Regency of Bengkulu Province and what was the legal impact on the issuance of coal mining licenses decisions that did not apply the precautionary principle?

\section{B. RESEARCH METHODOLOGY}

The research method is a system and a process that absolutely must be carried out in a scientific research and development activity. Research is a principal means of developing science in either technology or other fields. Research 
aims to reveal the truth systematically, methodologically, and with certainty. ${ }^{14}$ The research process is carried out through the analysis and construction of the data that have been collected and processed. ${ }^{15}$ The description contains in the research must also be done correctly, not to let the researcher only describe something only from hearing and or seeing it. Thus, this must be understood by a researcher, so that the results he will get will be in accordance with what he wants to achieve. ${ }^{16}$ A research requires a methodology which essentially provides guidance on the ways a scientist studies, analyzes and understands the environments he faces. $^{17}$

C. RESEARCH RESULTS AND DISCUSSION

\section{Application of Precautionary Principles in Issuance of Coal Mining Licenses at the Central Bengkulu Regency of Bengkulu Province.}

14 Soerjano Soekanto, Penelitian Hukum Normatif Suatu Tinjauan Singkat, Raja Grafindo Persada, Fourteenth Printing, 2012, p.1.

${ }^{15}$ Ibid., p. 3

${ }^{16}$ Sri Mamudji, et.al, Metode Penelitian dan Penulisan Hukum, Publishing Agency Faculty of Law, University of Indonesia, Jakarta, 2005, p. 21.

${ }^{17}$ Ibid, p. 6.
Since the development concept was implemented, matters relating to the management and protection of natural resources and the environment have become fundamental problems. Although the constitution stipulates that the control of natural resources was used maximally for the prosperity of the people, in fact until now the people have not been able to prosper with abundant natural resources, even though one of the goals of development is to improve the standard of living of their people. ${ }^{18}$

From the explanation above, actually Article 33 verse (3) of the 1945 Constitution of the Republic of Indonesia has laid a constitutional foundation for the use of living natural resources and their ecosystems in Indonesia from an early age. ${ }^{19}$ Likewise the state guaranteeing the rights of citizens to obtain basic rights to a good and healthy environment as stipulated in Article $28 \mathrm{H}$ verse (1) of the 1945 Constitution of the Republic of Indonesia. However, in its

\footnotetext{
${ }^{18}$ Kuncoro, in Sutikno and Maryunani, Ekonomi Sumberdaya Alam, Publishing Agency, Faculty of Economics, University of Brawijaya, Malang, 2006, p. 4. Maryana
} 
implementation, the state is often faced with a dilemma between utilization optimal with environmental and social losses.

Ideally, the state should make efforts to protect and manage the environment based on environmental norms, meaning in a balanced way between economic interests, preservation of environmental functions and social conditions. The Protection and management are carried out in an integrated manner covering all areas of the environment for the sustainability of environmental functions. In the end, balance and sustainability will be achieved in the welfare of the community. ${ }^{20}$

The precautionary principle shows that the state needs to be careful in making its policies. The activities that have the potential to cause serious and irreversible impacts which in this principle must be prevented. In this case, the lack of scientific certainty cannot be used as an excuse for delaying prevention efforts.

From the explanation above it could be said that the issuance of 9 (nine) coal mining licenses located at

\footnotetext{
${ }^{20}$ Op.Cit, Helmi. p. 46.
}

the Watershed of Air Bengkulu of Central Bengkulu Regency was not based on environmental instruments and ignored the principles of environmental conservation and protection, especially the precautionary principle and it could be said that the issuance of the license was legally flawed. Referring to the functional meaning of the existence of environmental protection and management permits in the context of environmental management supervision based on the realization of sustainable development as an effort to control environmental pollution and destruction, this was reflected in the level of comprehensiveness of permit requirements. ${ }^{21}$ To build an integrated licenses system in the environmental sector, it is also necessary to have an integrated regulatory system that does not just unify rules and administrations. Furthermore, integration means a substance which emphasizes that in implementing the licenses system, the principles of sustainable development must be used as a material legal basis. The implementation of licenses as a

\footnotetext{
${ }^{21}$ Suparto Wijoyo, Log.Cit.
} 
concrete form of implementation of environmental protection and management. Therefore, economic interests must be balanced with the interests of preserving environmental functions and social interests. ${ }^{22}$

Indicators of not applying the precautionary principle could also be seen from the policy or permit decisions on 9 (nine) coal mining licenses at the watershed of Air Bengkulu of Central Bengkulu Regency without considering the protection function/protected area, local protection function, life support function, the function of protecting the biodiversity of the area. The Government of Bengkulu Province should apply the precautionary principle to 9 (nine) coal mining licenses in the Watershed of Air Bengkulu of Central Bengkulu Regency because coal mining activities as described above have a high risk and have the potential to cause damage and pollution. Thus, in making decisions, the government of Bengkulu Province should consider the principles of environmental protection and

\footnotetext{
${ }^{22}$ Helmi, Log.Cit.
}

management which were one of the material requirements.

2. Legal Effects on the Issuance of Coal Mining Licenses Decisions that Do not Apply the Precautionary Principle.

In issuing licenses, the Government of Bengkulu Province especially in the coal mining sector has never applied the precautionary principle. These activities have the potential to cause serious and irreversible impacts which in this principle must be prevented. In this case, the lack of scientific certainty could not be used as an excuse for delaying prevention efforts. ${ }^{23}$

By not applying the precautionary principle in 9 (nine) coal mining licenses at the Watershed of Air Bengkulu of Central Bengkulu Regency, which was an essential requirement in a licenses decision, was a serious threat to environmental damage and pollution along with the the Watershed of Air Bengkulu of Central Bengkulu Regency. The government of Bengkulu Province

23 Liza Farihah \& Femi Angraini, Prinsip Kehati-Hatian Dan Kerugian Potensial Dalam Perkara Tata Usaha Negara Terkait Lingkungan Hidup, Yudisial Journal Vol. 5 No. December $3 \mathrm{r}^{\mathrm{d}}$, 2012, p. 245. 
should have enforced the government against 9 (nine) coal mining licenses at the Watershed of Air Bengkulu. This was a concrete step to prevent environmental damage and pollution since the application of the precautionary principle is an obligation in the process and implementation of coal mining licenses which have a high risk of environmental damage and pollution.

In the field of administrative law, there were 3 (three) nullification theories (nietig theory), namely absolute nullity (absolute nietig), void (nietig van rechtwege), and can be canceled (vernietig baar). Lack of material and essential requirements in the decision to issue 9 (nine) coal mining licenses in the Watershed of Air Bengkulu of Central Bengkulu Regency by the Government of Bengkulu Province by not implementing the precautionary principle, the government of Bengkulu Province should be able to take legal action (nietig van rechtwege) and can be canceled (vernietig baar) against the decision to issue 9 (nine) coal mining licenses at the Watershed of Air Bengkulu of Central Bengkulu
Regency because the government of Bengkulu Province has the authority to cancel the licenses decision and is a State Administration official.

The decision on Lawsuits for Unlawful Acts with case number 44/Pdt.G/LH/2018/PN.Bgl between WALHI and PT. Kusuma Raya Utama has implications for the impunity of the 8 coal mining companies that carry out coal mining activities at the Watershed of Air Bengkulu of Central Bengkulu Regency in applying the ecocide concept to environmental destroyers. If it is withdrawn more widely, the 9 coal mining companies have committed serious human rights violations equivalent to crimes of genocide and other crimes against humanity. This is because the position of the ecocide is a modern crime equivalent to other international crimes mentioned in the Rome Statute. This is based on action, involvement, and its impact on the essence of peace and peace of the population, the right to life, and the preservation of human life and the present and future environment.

\section{CLOSING}

\section{Conclusion}


In publishing 9 (nine) coal mining licenses at the Watershed of Air Bengkulu of Central Bengkulu Regency, the Government of Bengkulu Province did not apply the precautionary principle, ignored environmental instruments, did not consider the environmental function of the the Watershed of Air Bengkulu of Central Bengkulu Regency, and ignored essential and material requirements. Therefore the decision to issue coal mining licenses was null, void (nietig van rechtwege) or could be canceled (vernietig baar), these actions could be carried out by the government of Bengkulu Province as an effort to enforce administrative law.

\section{Suggestion}

In issuing licenses, especially in the field of mining coal, the Government of Bengkulu Province must consider and must apply the precautionary principle because it is essential requirements and material requirements in a licenses decision making to prevent damage to environmental functions in Bengkulu Province, because as it is known that licenses is a preventive instrument to prevent environmental damage. the
Government of Bengkulu Province must also be firmer in imposing administrative sanctions on coal mining companies that destroy and pollute the environment, especially at the Watershed of Air Bengkulu of Central Bengkulu Regency, so that justice between generations can be realized and the goals of sustainable development can be achieved.

\section{REFERENCES}

\section{Books}

Abdulah Marlang dan Rina Maryana, 2015, Hukum Konservasi Sumber Daya Alam Hayati dan Ekosistemnya, Mitra Wacana Media, Jakarta

Abdulkadir Muhamad, 2004, Hukum dan Penelitian Hukum, Penerbit : PT. Citra Bhakti, Bandung

Abrar Saleng, 2004, Hukum Pertambangan, Universitas Islam Indonesia Press, Yogyakarta.

Adrian Sutedi, 2012,Hukum Pertambangan, Sinar Grafika, Jakarta.

Amir Llyas, 2012, Asas-asas Hukum Pidana, Rangkang Education \& PuKAP Indonesia, Yogyakarta.

Alwiya Shabanu, et all, 2018,Oligarki Ekstraktif dan Penurunan Kualitas Hidup Rakyat, Deadly Coal Series-4, JATAM, Jakarta.

Andri G Wibisana, 2017, Penegakan Hukum Lingkungan melalui pertanggungjawaban Perdata, Badan Penerbit FH UI, Depok.

Andi Hamzah, 2004,Asas-Asas Hukum Pidana, PT. Rineka Cipta, Jakarta 
Bambang sugono, 2012, metode penelitian hukum, Jakarta, Rajawali Pers

Daud Silalahi, 1992, Hukum Lingkungan Dalam Sistem Penegakan Hukum Lingkungan Di Indonesia, Penerbit Alumni, Bandung.

Chay Asdak, 2014, Kajian Lingkungan Hidup Strategis, jalan menuju pembangunan berkelanjutan.

S.T. Kansil dan Christine S.T,1995, "Latihan Ujian Hukum Pidana", Sinar Grafika, Jakarta.

Djoko Prakoso, 1998, Hukum Penitensier di Indonesia, Liberty, Yogyakarta.

Emil Salim, 1986, Pembangunan Berwawasan Lingkungan, LP3ES, Cetakan ke-1, Jakarta.

Emil Salim, Thoby Mutis. 2009,Instrumentasi dan Standarisasi Kebijakan Pengelolaan Lingkungan Hidup, Penerbit Universitas Trisakti, Jakarta

E. Y. Kanter dan S.R. Sianturi, 2002, Asas-asas Hukum Pidana Di Indonesia dan Penerapannya”, Storia Grafika, Jakarta.

Gatot Supramono, 2013, Penyelesaian Sengketa Lingkungan Hidup di Indonesia, Rineka Cipta, Jakarta.

Harun M. Husein, 1995, Lingkungan Hidup Masalah, Pengelolaan dan Penegakan Hukumnya, Bumi Aksara, Jakarta.

Hasni, 2010, Hukum Penataan Ruang dan Penatagunaan Tanah, PT RajaGrafindo Persada, Jakarta

Helmi, Hukum Perizinan Lingkungan Hidup, Cetakan Pertama, Sinar Grafika, Jakarta.

Iskandar, 2015, Hukum Kehutanan Prinsip Hukum Pelestarian Fungsi Lingkungan Hidup Dalam Kebijakan Pengelolaan Kawasan Hutan Berkelanjutan, Mandar Maju, Bandung.
JuniarsoRidwandanAchmatSodik,2013,HukumTat aRuangDalamKonsepKebijakanOtonomiDa erah,Nuansa,Bandung.

Jimly Asshiddiqi, 2010, Green constitution, Nuansa hijau Undang-undang Dasar Negara Republik Indonesia Tahun 1945.

Josef Thessing dan Wilhelm Hofmeister, 1996, Environment and Development Protection as An Element of Order Policy, Rathausallee: Konrad Adenauer Stiftung.

Kuncoro, Dalam Sutikno dan Maryunani, 2006,Ekonomi Sumberdaya Alam, Badan Penerbit Fakultas Ekonomi Universitas Brawijaya, Malang.

N.M.Spelt dan J.B.J.M. ten Berge, 1993, Pengantar Hukum Perizinan, Yuridika, Surabaya.

M. Ridha Saleh et all, 2019, Ecocide Memutus Impunitas Korporasi, WALHI, Jakarta.

Mas Ahmad Sentosa, 1999, Demokratisasi Pengelolaan Sumber Daya alam, ICEL, Jakarta.

Mas Achmad Santosa, 2001, Good Governance \& Hukum Lingkungan, Penerbit ICEL, Jakarta.

Moeljatno, 1993, Asas-asas Hukum Pidana, Sinar Grafika, Jakarta.

NHT. Siahan, 2009, Hukum Lingkungan, Cetakan Kedua, Pancuran Alam, Jakarta.

Otto Soemarwoto, 1994, Ekologi, Lingkungan Hidup.dan Pembangunan, Cetakan Keenam, Penerbit Djambatan, Jakarta

Prajudi Atmosudirdjo,1983,Hukum Administrasi Negara, Edisi Revisi, Ghalia Indonesia, Jakarta.

R. Abdoel Djamali, 2010, Pengantar Hukum Indonesia, Rajawali Pers,Jakarta

Rentowulan Sutanto dan Iskandar Oeripkartawinata, 1999, Hukum Acara Perdata dalam Teori dan Praktek, Mandar Maju, Bandung. 
Ridwan HR, 2005, Hukum Administrasi Negara, Edisi Revisi, PT. Raja Grafindo Persada, Jakarta.

Ridwan H.R, 2009, Tiga Dimensi Hukum Administrasi dan Peradilan Administrasi, FH UII Press, Yogyakarta.

Saifudin Azwar, 2011, Metode Penelitian, Penerbit: Pustaka Pelajar, Yogyakarta.

Samsul Wahidin, 2014, Dimensi Hukum Perlindungan dan Pengelolaan Lingkungan Hidup, Pustaka Belajar, Yogyakarta.

Siti Sundari Rangkuti, 2005, Hukum Lingkungan dan Kebijaksanaan Lingkungan Nasional, Edisi Ketiga, Airlangga University Press, Surabaya.

Soerjano Soekanto, 2012, Penelitian Hukum Normatif Suatu Tinjauan Singkat, R Grafindo Persada, Cetakan keempat belas

Suparto Wijoyo, 2005, Refleksi Matarantai Pengaturan Hukum Pengelolaan Lingkungan Secara Terpadu (Studi Kasus Pencemaran Udara), Airlangga University Press, Surabaya.

Sri Mamudji, et.al, 2005, Metode Penelitian dan Penulisan Hukum, Badan Penerbit Fakultas Hukum Universitas Indonesia, Jakarta.

Syahrul Machmud, 2012, Penegakan Hukum Lingkungan Indonesia, Graha Ilmu, Yogyakarta.

Suparto Wijoyo, Penyelesaian Sengketa Lingkungan(Settlement of Environment Disputes), Airlangga University Press, Surabaya.

Taqwaddin,2011, Aspek Hukum Kehutanan \& Masyarakat Hukum Adat di Indonesia, Intan Cendekia, Yogyakarta.

\section{Journal/Article}

Aditya Saprillah, Penegakan Hukum Administrasi Lingkungan Melalui Mekanisme
Pengawasan, Jurnal Bina Hukum Lingkungan, Vol. 1, Nomor 1, Tahun Oktober 2016.

Andri G Wibisana, Konstitusi Hijau Perancis: Komentar atas Asas Kehatihatian dalam Piagam Lingkungan Perancis 2004, Jurnal Konstitusi, Vol. 8, Nomor 3, Juni 2011.

Daud Silalahi, Pembangunan Berkelanjutan Dalam Rangka Pengelolaan (Termasuk Perlindungan) Sumber Daya Alam Yang Berbasis Pembangunan Sosial Dan Ekonomihal, Makalah Seminar Pembangunan Hukum Nasional VIII, Badan Pembinaan Hukum Nasional, 2003.

Diana E. Rondonuwu, Tinjauan Yuridis Terhadap Penegakan Hukum Lingkungan Administratif Menurut Undang-Undang Nomor 32 Tahun 2009, Lex Privatum, Vol VI, Nomor 9, Tahun November 2018.

Efendi, Kajian Model Pengelolaan Daerah Aliran Sungai (DAS) Terpadu, Direktorat Kehutanan dan Sumber Daya Air BAPPENAS RI.

Edra Satmaidi, "Kajian Lingkungan Hidup Strategis (KLHS) dalam Menjamin Terpeliharanya Daya Dukung dan Daya Tampung Lingkungan Hidup (DDDTLH) Bagi Pembangunan Berkelanjutan", Indonesian Journal Of Dialectics, vol. 5, No 3 Desember 2015.

Efendi, Penerapan Prinsip Pengelolaan Hidup Dalam Peraturan Perundang-Undangan di Bidang Sumber Daya Alam, Kanun Jurnal Ilmu Hukum, No. 58 Tahun XIV (Desember 2012).

Global Witness, Executive Summary; On Dangerous Ground, Executive Summary, 2015.

Hardjaloka L, "Ketepatan Hakim dalam Penerapan Precautionary Principle sebagai "Ius Cogen" dalam Kasus Gunung Mandalawangi Kajian 
Putusan Nomor 1794K/Pdt/2004” Jurnal Yudisial, (2 Agustus 2012).

Herlambang P. Wiratraman, dalam paparan "Kontekstualisasi Buku Memutus Hak Impunitas Korporasi" di kantor, Eksekutif Nasional WALHI, 2019.

Iskandar, Perlindungan hukum Kawasan Hutan di Provinsi Bengkulu Ditinjau Dari Segi Hukum Lingkungan Administrasi, Jurnal Ilmu Hukum KANUN Nomor 38 Tahun XIV April 2004.

Iskandar, Keabsahan Tindakan Pemerintah Dalam Hal Penerbitan dan Pembatalan Keputusan Gubernur Bengkulu, Jurnal Ilmu Hukum, Maret Tahun 2014.

La Ode Angga, Prinsip Kehati-hatian di Bidang Pengelolaan Lingkungan Hidup Dalam Peraturan Daerah Rencana Tata Ruang Wilayah Provinsi Maluku, Rechtidee, Vol. 12. Nomor 1 Juni 2017.

La Ode Angga, Penerapan Prinsip Kehati-hatian dalam Kebijakan Perlindungan dan Pengelolaan Lingkungan Hidup di Bidang Pertanian Untuk Keunggulan Varietas Produk Rekayasa Genetika , Supremasi Hukum, Vol. 3. Nomor 2 Desember 2014.

Liza Farihah \& Femi Angraini, Prinsip KehatiHatian Dan Kerugian Potensial Dalam Perkara Tata Usaha Negara Terkait Lingkungan Hidup, Jurnal Yudisial Vol. 5 No. 3 Desember 2012.

Melda Kamil A Ariadno, Prinsip-prinsip Dalam Hukum Hukum Lingkungan Internasional, Hukum Lingkungan Internasional, Nomor 2 Tahun XXIX.

Mukhlish, Konsep Hukum Administrasi Lingkungan Dalam Mewuudkan Pembangunan Berkelanjutan, Jurnal Konstitusi, Volume 7, Nomor 2, April 2010.

Muladi, Prinsip-Prinsip Dasar Hukum Pidana Lingkungan dalam Kaitannya dengan Undang-undang Nomor 23 Tahun 1997,
Jurnal Hukum Pidana dan Kriminologi, Vol. 1, Nomor I, Tahun 1998.

Samsu, Final Laporan Daerah Aliran Sungai Bengkulu, Yayasan Ulayat, Bengkulu, Tahun 2005.

Supriyono dkk, Kajian Dampak Penambangan Batu Bara Terhadap Kualitas Air dan Arahan Mitigasi Sungai di Sub DAS Hilir Sungai Bengkulu, Jurnal Geografi Universitas Negeri Padang, Vol. 4 No. 2 Oktober 2015.

Sulistiyono, Pengaruh Izin Lingkungan sebagai Upaya Preventif Terhadap Perlindungan dan Pengelolaan Lingkungan Hidup Untuk Mencegah Kerusakan Lingkungan Hidup, Jurnal Forum Teknologi, Vol. 6 Nomor 4.

Nanang Indra Kurniawan, Wacana Lingkungan dan Pembangunan Berkelanjutan dalam Lembaga Swadaya Masyarakat di Indonesia, Jurnal Ilmu Sosial dan Ilmu Politik, Vol. 16 Nomor 1, Tahun 2012.

Police Brief, Urgensi Moratorium Izin Tambang Untuk Tata KelolaLingkungan Hidup yang Berkeadilan, WALHI, Bengkulu, 2017.

\section{Website}

https://www.mongabay.co.id/2017/04/30/aktivitastambang-batubara-yang-meresahkan-dihulu-das-air-bengkulu/

https://bengkulutengahkab.go.id/selayangpandang/ iklim-dan-topologi-Topografi

\section{Regulation}

Undang-Undang Dasar Negara Republik Indonesia Tahun 1945;

Undang-Undang Nomor 23 Tahun 2014 tentang Pemerintah Daerah;

Undang-Undang Nomor 4 Tahun 2009 tentang Mineral dan Batu Bara; 
Undang-Undang Nomor 32 Tahun 2009 Peraturan Daerah Provinsi Bengkulu Nomor 1 tentang Perlindungan dan Pengelolaan Lingkungan Hidup; Tahun 2017 tentang Pengelolaan Daerah Aliran Sungai;

Peraturan Pemerintah Nomor 37 Tahun 2012 tentang Pengelolaan Daerah Aliran Sungai

Peraturan Daerah Provinsi Bengkulu Nomor 2 Tahun 2012 tentang Rencana Tata Ruang Wilayah Provinsi Bengkulu; 